\title{
PLURIATIVIDADE NA AGRICULTURA FAMILIAR NO COMPARTIMENTO ARENÍTICO DA BACIA HIDROGRÁFICA DO RIO PIRAPÓ - PARANÁ/BRASIL
}

\section{PLURIATIVITY IN FAMILY AGRICULTURE IN THE SANDSTONE COMPARTMENT OF PIRAPÓ RIVER BASIN - PARANÁ/BRASIL}

\begin{abstract}
Tsugie Kawano
Doutoranda em Dinâmica dos Espaços Rurais e Urbanos pelo Programa de Pós-Graduação em Geografia UNICENTRO, Guarapuava-PR, Brasil oycarmen@msn.com
\end{abstract}

Hélio Silveira Professor Doutor do Departamento de Geografia e do Programa de Pós-Graduação em Geografia da Universidade Estadual de Maringá, Maringá-PR, Brasil hesilveira70@hotmail.com

Elpídio Serra Professor Doutor do Departamento de Geografia e do Programa de Pós-Graduação em Geografia da Universidade Estadual de Maringá, Maringá-PR, Brasil elpidioserra@hotmail.com

Carlos Henrique da Graça Doutor pelo Programa de Pós-Graduação em Geografia Universidade Estadual de Maringá, Maringá-PR, Brasil henriquechg@gmail.com

\section{Resumo}

O presente trabalho tem como objetivo analisar a pluriatividade na agricultura familiar no compartimento arenítico da bacia hidrográfica do rio Pirapó - Paraná/Brasil, a fim de compreender as suas estratégias de reprodução social e econômica nesse setor da bacia, que tem como atributo o predomínio de solos de textura média e arenosa, os quais são suscetíveis à erosão e pobres em elementos químicos. Para o desenvolvimento deste trabalho, as atividades foram segmentadas em três etapas: a primeira foi sustentada em referências bibliográficas; a segunda envolveu o levantamento de dados agropecuários do Instituto Brasileiro de Geografia e Estatística; e por último foi o trabalho de campo e a elaboração dos mapas temáticos. Para a coleta de dados, foram aplicados questionários com os produtores rurais familiares da referida unidade de paisagem. A pesquisa demonstrou que, nas propriedades estudadas, o uso desses solos, que possuem pouca capacidade produtiva em função de sua característica natural, foi principalmente para a pastagem destinada à criação de gado de corte e de leite, e como essa atividade é mais rentável em extensas áreas, como estratégias de reprodução social e econômica, os produtores familiares praticam a pluriatividade.

Palavras-chave: Pluriatividade. Agricultura familiar. Bacia hidrográfica. Noroeste do Paraná. 


\section{Abstract}

The aim of this study is analyzing the pluriativity in family agriculture in the sandstone compartment of Pirapó River Basin - Paraná/Brazil, in order to understand their strategies of social and economic reproduction. One of the attributes of this sector of the basin is the prevalence of soil of medium and sandy texture, which is susceptible to erosion and poor in chemical elements. This study was conducted through activities that were divided into three stages: the first one was based on a bibliographic review; the second involved the collection and analysis of agricultural data from the Brazilian Institute of Statistical Geography; the last one consisted of a fieldwork and the creation of thematic maps. The data were collected through questionnaires answered by family rural producers. The research demonstrated that, in the rural properties that took part in the study, the soil, whose productive capacity is low due to its natural characteristics, is mainly used for pastures to feed dairy and beef cattle. Since this activity is more profitable in extensive areas, the producers adhere to pluriactivity as a strategy of social and economic reproduction.

Keywords: Pluriactivity. Family farming. Hydrographic basin. Northwest of Paraná.

\section{Introdução}

O uso da terra nas áreas do Norte do Paraná e, consequentemente, na área da bacia do Pirapó, desde o início da efetiva colonização, foi destinado à lavoura cafeeira. Segundo Cancian (1977, p. 103), "todo Norte do Paraná foi dominado por verdadeiro mar de cafezais, até meados da década de 1960”. Começou o seu declínio em função de vários fatores, tais como: o excesso de produção, resultando na erradicação dos cafezais; as sucessivas geadas, principalmente a de 1975, que praticamente dizimou a cultura cafeeira do Norte do Paraná; as leis trabalhistas rurais em 1963; mercados internacionais; o esgotamento do solo; o surgimento de novos modelos agrícolas; assim como também a ação governamental, com programas de diversificação das atividades agrícolas.

A intensa geada de 1975, que destruiu a lavoura cafeeira, fez com que acelerasse o seu processo de substituição por lavouras mecanizadas de soja, trigo e milho, em solos oriundos do basalto. Porém, em solos derivados do arenito da Formação Caiuá, o café passou a ser substituído por lavouras de algodão. Posteriormente, a pastagem, destinada principalmente ao gado de corte, foi ganhando espaço, se tornando a atividade econômica 
predominante. E a partir da década de 1990, as lavouras de cana-de-açúcar passam a ser cultivadas para abastecer as usinas de açúcar e álcool (NÓBREGA e SERRA, 2009).

Nos solos originários da alteração dos arenitos, principalmente da Formação Caiuá, que se encontra no Noroeste do Paraná, logo após a derrubada da floresta nativa, foram introduzidas culturas de café e algodão, sem considerar as suas características pedológicas. Assim, diversos autores verificaram que, nesses solos de textura média e arenosa, o manejo inadequado causou a diminuição da fertilidade natural dos solos e o desencadeamento de vários processos erosivos (BIGARELLA e MAZUCHOWSKI, 1985; FASOLO et al., 1988; NAKASHIMA,1999).

Diante disso, atualmente, tem-se como uso predominante do solo a pastagem plantada, seguida pela cana-de-açúcar, pois são culturas que se adaptam a essas condições naturais de solo e clima. Essas culturas necessitam de extensas áreas para serem economicamente rentáveis; portanto, esse é outro fator pelo qual os produtores ocupam as terras desse setor da bacia do Pirapó para essas atividades agropecuárias, cujos preços das terras são inferiores em relação às áreas de solos argilosos. Isso porque não disponibilizam de boas condições naturais para determinadas culturas, pois nesse compartimento de paisagem, encontram-se solos de textura média principalmente e arenosa, os quais são suscetíveis à erosão, pobres em elementos químicos, com baixa capacidade de reter umidade. Além disso, temperaturas mais elevadas e os menores valores pluviométricos no estado do Paraná levam invariavelmente ao maior risco de fracasso de determinadas atividades. A baixa fertilidade do solo pode ser corrigida com adubação, porém necessita que o produtor tenha maiores investimentos com o emprego de fertilizantes, para alcançar uma melhor produção agrícola.

Nos municípios onde predominam solos oriundos da decomposição do arenito da Formação Caiuá, com o novo modelo agrícola, áreas menores passaram a ter dificuldades para se manterem. Com o uso do solo voltado, principalmente, para a pastagem plantada, seguido pela cana-de-açúcar e cultura de grãos (soja, trigo e milho), os quais exigem extensas áreas para serem economicamente rentáveis, a sobrevivência dos agricultores familiares foi ficando cada vez mais difícil. Assim, de acordo com Fleischfresser (1988), as condições materiais, bem como o tamanho da área, são, para uns, oportunidade; para outros, uma barreira à introdução do progresso técnico e à apropriação de seus frutos. 
Sendo assim, nos dias atuais, a alternativa para o pequeno proprietário desse setor da bacia que não dispõe de capital para se adequar ao novo modelo agrícola é diversificar a sua produção com culturas como a mandioca, o café, o urucum, a criação de pequenos animais (aviários, suínos, ovinos, caprinos), laranja, entre outros, e praticar a pluriatividade. Outra alternativa é arrendar ou vender as suas terras para os grandes produtores rurais e abandonar o campo. Segundo Serra (2010), as pequenas propriedades, não tendo como se manter economicamente, se tornaram vulneráveis à incorporação pelas médias e grandes propriedades.

Nesse contexto da diversificação de atividades, a pesquisa realizada por Vizintim et al. (2012) sobre a produção familiar constatou que o sistema de produção diversificada é uma estratégia adotada para o pequeno produtor conseguir se manter no campo, pois quanto maior a diversificação do sistema produtivo, menores são os riscos, além de gerar maior renda por hectare produzido.

Como foi verificado anteriormente, a principal atividade econômica desse compartimento, que possui solos derivados de rochas areníticas, é a pastagem, seguida pela cana-de-açúcar, pois essas culturas se adaptam a solos com reduzida fertilidade natural. Porém, para ser economicamente rentável, necessita de grandes extensões de área. E para se cultivar outras lavouras que necessitam de solos com uma razoável fertilidade natural, necessita de investimentos na correção, e adubação. Portanto, diante desses fatores, os agricultores familiares dessa unidade de paisagem que não dispõem de extensas áreas e tecnologias que demandam capital buscam na pluriatividade a possibilidade de sua reprodução econômica e social.

Diante disso, segundo Silva (2016, p. 258):

A pluriatividade seria um fenômeno resultante de um amplo processo de transformação agrícola inteiramente ligado à dinâmica geral da economia (divisão do trabalho), mas que guarda certas especificidades de acordo com as condições geográficas existentes e os contextos político e econômico nos quais as unidades familiares estão inseridas.

Contudo, o fenômeno da pluriatividade, segundo o mesmo autor, é a combinação entre atividades agrícolas e não agrícolas em um determinado contexto territorial (SILVA, 2016). 
O fenômeno da pluriatividade, de certa maneira, é um fenômeno tanto antigo como recente no Brasil (CARNEIRO, 1998). A prática de atividades não agrícola para complementar a renda já se encontrava presente na vida do campesinato. Porém, os estudos sobre o termo "pluriatividade" começam a ganhar força entre meados da década de 1980 e início da década de 1990, quando surgiram os primeiros estudos sobre a agricultura em tempo parcial (part-time farming), especificamente na Região Sul do país (ANJOS, 2003). Segundo o autor, o fato de esse fenômeno ter ganhado maior relevância nessa região se deve a questões históricas, pois é onde está o mais importante setor de agricultores familiares do Brasil e onde se encontram os colonos provenientes da Europa, que são os alemães, os italianos e poloneses, os quais possuem traços típicos do campesinato centro-europeu, principalmente no que se refere ao dinamismo para a diversificação econômica das unidades familiares de produção.

O termo pluriatividade, segundo o conceito de Schneider (2003), é

[...] um fenômeno através do qual membros das famílias de agricultores que habitam no meio rural optam pelo exercício de diferentes atividades, ou mais rigorosamente, optam pelo exercício de atividades não-agrícolas, mantendo a moradia no campo e uma ligação, inclusive produtiva, com a agricultura e a vida no espaço rural (SCHNEIDER, 2003, p. 91).

Diante disso, o fenômeno da pluriatividade, na concepção desse autor, refere-se à combinação de atividades agrícolas com atividades não agrícolas "Essa combinação permanente de atividades agrícolas e não-agrícolas, em uma mesma família, é que caracteriza e define o fenômeno denominado de pluriatividade" (SCHNEIDER, 2003, p. 14).

A pluriatividade também serve para mostrar a transição da própria função da agricultura que, além de produzir alimentos e gerar emprego, favorece o processo de acumulação de capital, e contribui na preservação ambiental, na dinamização e desenvolvimento do espaço rural. Diante disso, as famílias pluriativas são agentes capazes de frear a saída brusca da população das áreas rurais, dando um novo sentido ao processo de produção do espaço rural (MATTEI, 2007).

Há estudiosos que argumentam que a pluriatividade seria uma característica passageira ou transitória que poderia desaparecer. Porém, Abramovay (2003) argumenta que essa grande massa de agricultores pluriativos considerados, durante os anos 1970, 
como inviáveis e condenados ao desaparecimento preenche funções sociais cada vez mais valorizadas em relação à ocupação do território e à preservação do patrimônio cultural e ambiental.

Existem também os que se encantaram com as potencialidades da pluriatividade e das atividades não agrícolas no desenvolvimento rural, porém sem levarem em consideração o lugar e o contexto em que esses processos puderam emergir e se desenvolver (SCHNEIDER, 2003). Segundo o autor, a pluriatividade não é um fenômeno marginal ou transitório nem é padrão em todo o território brasileiro.

No âmbito externo, houve um debate entre os especialistas europeus sobre a questão de a pluriatividade ser uma realidade social nova ou antiga. Para alguns, o campesinato sempre foi pluriativo e o que estaria ocorrendo hoje é um "refortalecimento de uma prática histórica que, durante um determinado período, havia sido alvo de tentativa de eliminação, com o incentivo da modernização e especialização dos agricultores familiares", mas há quem considere uma nova forma, pois não é mais aquela antiga precariedade de acesso ao mercado; envolve uma multiplicidade de estratégias (ALENTEJANO, 2001, p. 150).

Segundo Silveira, Neumann e Santos (2004), são várias as situações que levam à ocorrência da pluriatividade: o tempo ocioso na unidade de produção, a necessidade de complemento de renda, adaptação a novas realidades, dentre outros. De acordo com os autores, a ocorrência e as particularidades desse fenômeno dependem das circunstâncias do meio no qual ela está inserida, sendo que o grau de desenvolvimento da região ou do país é decisivo para determiná-la.

Ainda, dentro dos fatores que contribuem para a emergência da pluriatividade, porém internos à unidade familiar, encontram-se a idade, o número de membros da família, a escolaridade, a disponibilidade de terra etc. e os contextos e ambientes socioeconômicos em que se desenvolve (SCHNEIDER et al., 2013).

Para esta pesquisa, levaram-se em conta as características físicas da propriedade rural. Isso porque, de acordo com Schneider (2009), a pluriatividade é heterogênea, diversificada e pode estar ligada às estratégias sociais e produtivas adotadas pela família e seus membros; além disso, a sua variabilidade dependerá das características do contexto ou do território em que estiver inserida. 
Justifica-se a escolha da referida unidade de paisagem para o desenvolvimento desta pesquisa, devido ao fato de não haver estudos sobre o fenômeno da pluriatividade nesse setor da bacia hidrográfica, onde há predomínio de pequenos estabelecimentos agrícolas. Cabe lembrar que, de acordo com Anjos (2003), a pluriatividade é um fenômeno que está associado à agricultura familiar.

Esse setor da bacia apresenta solos com deficiências nutricionais devido às suas características naturais, sendo que o predomínio do seu uso é a pastagem destinada, principalmente, à criação de gado de corte e de leite, seguida pela cana-de-açúcar e outros usos bem diversificados, com a criação de pequenos animais, tais como: galináceos, suínos, ovinos, caprinos etc. Em virtude disso, Parte-se do princípio de que os produtores familiares praticam atividades não agrícolas articuladas à essas atividades agropecuárias.

Pela importância da agricultura familiar na produção de alimentos no Brasil e das transformações que essa categoria social vem passando ao longo do tempo, este trabalho tem como objetivo analisar as propriedades familiares pluriativas no compartimento arenítico da bacia hidrográfica do rio Pirapó-PR, a fim de compreender as suas estratégias de reprodução social e econômica nesse setor da bacia, que tem como atributo o predomínio de solos de textura média e arenosa, os quais são suscetíveis à erosão e pobres em elementos químicos.

A bacia hidrográfica do rio Pirapó situa-se no Terceiro Planalto Paranaense, nas mesorregiões geográficas Norte Central e Noroeste do Paraná (Mapa 1). Localiza-se entre as latitudes de $22^{\circ} 32^{\prime} 30^{\prime \prime} \mathrm{S}$ e $23^{\circ} 36^{\prime} 18^{\prime \prime} \mathrm{S}$ e longitudes de $51^{\circ} 22^{\prime} 42^{\prime \prime} \mathrm{W}$ e $52^{\circ} 12^{\prime} 30^{\prime \prime} \mathrm{W}$ (PARANÁ, 2013). Apresenta uma área total de $5.098,12 \mathrm{~km}^{2}$, que corresponde a $3 \%$ da área do estado (ITCG, 2010). O rio Pirapó nasce no município de Apucarana, a $1.000 \mathrm{~m}$ de altitude, percorrendo uma extensão de $168 \mathrm{~km}$ até sua foz, no rio Paranapanema, a 300 m de altitude, no município de Jardim Olinda. 


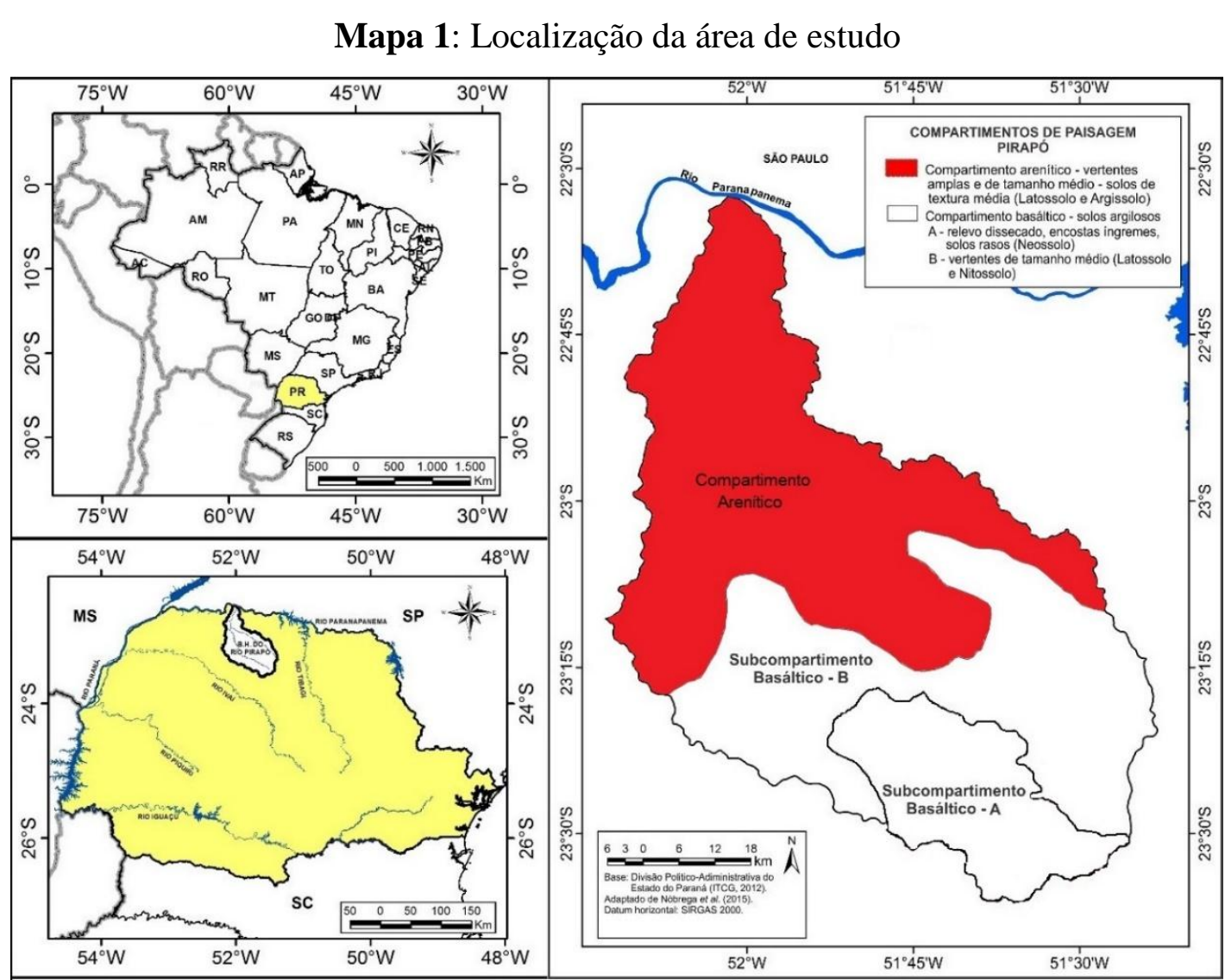

Fonte: Adaptado de Nóbrega et al., 2015.

Org: Elaborado pelos autores, 2020.

São 22 municípios que estão totalmente ou parcialmente inseridos no compartimento arenítico, conforme mostra o Mapa 2: Ângulo, Astorga, Atalaia, Colorado, Cruzeiro do Sul, Flórida, Guaraci, Iguaraçu, Itaguajé, Jaguapitã, Jardim Olinda, Lobato, Mandaguaçu, Munhoz de Mello, Nossa Senhor das Graças, Nova Esperança, Paranacity, Paranapoema, Presidente Castelo Branco, Santa Fé, Santa Inês, Uniflor.

A região comumente chamada de Norte do Paraná foi dividida em três áreas de acordo com a época e origem da respectiva colonização: Norte Velho, Norte Novo e Norte Novíssimo (CMNP, 1975). A bacia do Pirapó situa-se no Norte Novo e no Norte Novíssimo, que corresponde à "mesorregião" Norte Central e Noroeste Paranaense, respectivamente. 
Mapa 2: Municípios pertencentes total ou parcialmente à bacia hidrográfica do rio

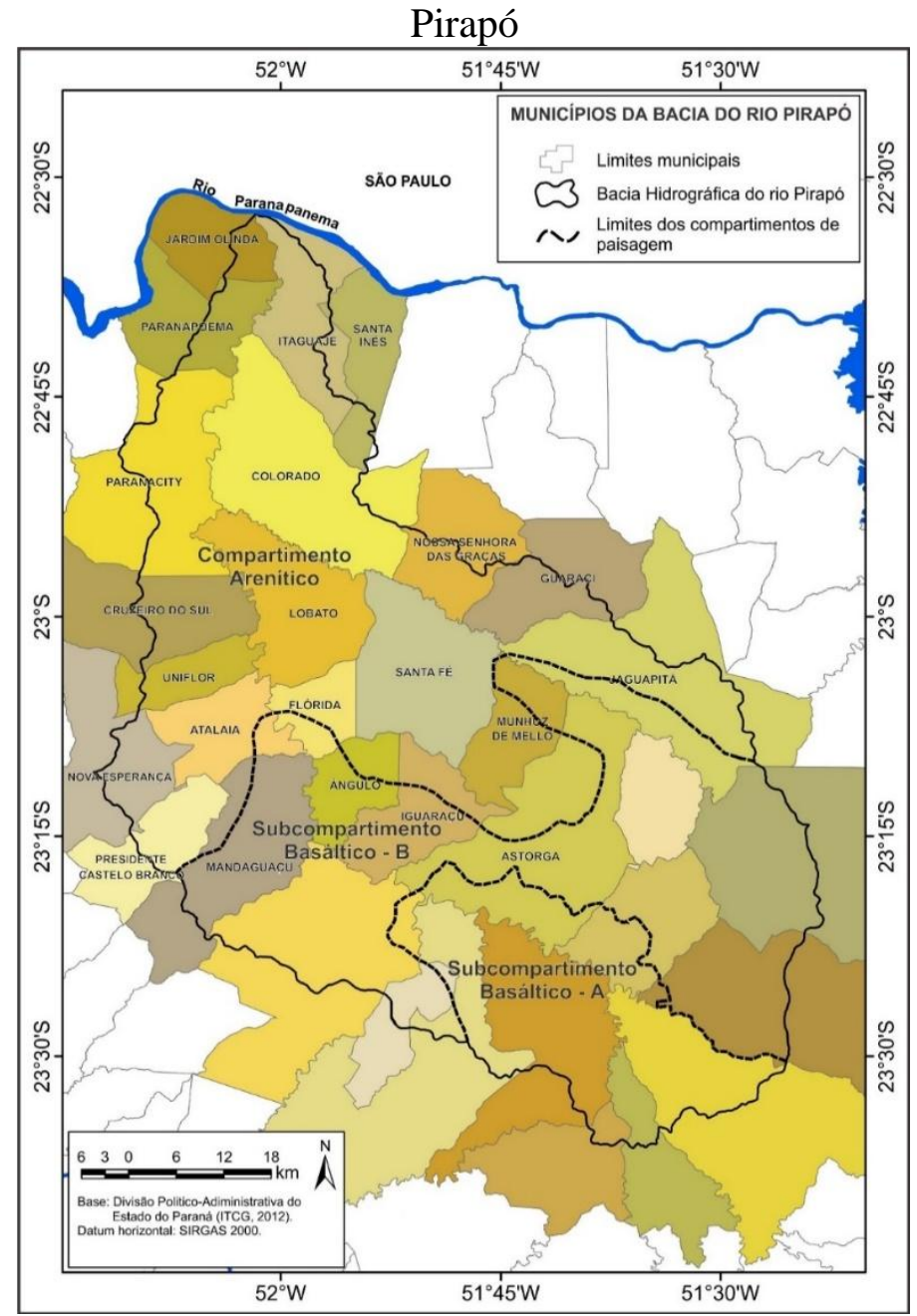

Org: Elaborado pelos autores, 2020.

A pesquisa está baseada na compartimentação da paisagem proposta por Nóbrega et al. (2015) para a bacia do Pirapó, onde identificaram dois grandes compartimentos: compartimento arenítico e compartimento basáltico, seguindo os critérios da caracterização física da bacia. Essa compartimentação da bacia resulta das características físicas; portanto, da variação do substrato geológico que contrapõe rochas ígneas de origem vulcânica e rochas sedimentares areníticas.

O compartimento arenítico corresponde ao médio-baixo e baixo curso do Pirapó, que tem como substrato geológico os arenitos, principalmente das Formações Caiuá e Santo Anastácio e, em menor proporção, da Formação Adamantina. 
O compartimento basáltico corresponde ao médio-alto e alto curso do Pirapó, o qual está assentado sobre os basaltos da Formação Serra Geral, diferenciado entre subcompartimento A e subcompartimento B (Mapa 1).

Visando a um estudo de forma integrada dos seus elementos naturais e os aspectos socioeconômicos, utilizou-se a análise integrada da paisagem estabelecida por Monteiro (2001). Essa análise permite avaliar, de forma integrada, a estrutura geoecológica e a estrutura socioeconômica (natureza-homem), permitindo estabelecer as suas relações na área de estudo, buscando compreender o uso e a ocupação do solo nas propriedades rurais desse compartimento de paisagem arenítico e as relações com as suas estruturas físicas naturais.

Com uma análise integrada da paisagem, é possível avaliar o conjunto dos elementos abióticos, bióticos e antrópicos, pois esses elementos interagem de forma sistêmica. Segundo Bertrand e Bertrand (2009), os elementos abióticos são os que estruturam o sistema, como a rocha, o ar, a água; os elementos bióticos, que indicam o funcionamento do sistema, são os animais, vegetais e solos; e os elementos antrópicos são os que transformam e constroem novas formas, que seria o impacto da sociedade sobre o seu meio ambiente material. Contudo, os estudos integrados que compõem o meio físico permitem uma interpretação ambiental integrada, tanto no nível de bacias hidrográficas quanto de sistemas ambientais mais complexos e em nível de municípios.

Para efeito de identificação da propriedade, em função de sua dimensão, elas foram classificadas como pequena, média e grande, seguindo os padrões estabelecidos pelas companhias colonizadoras que atuaram na região, repartindo e comercializando lotes rurais durante a fase da ocupação pioneira. Para as empresas colonizadoras, a pequena propriedade tinha até 10 hectares, a média propriedade entre 10 e 50 hectares e a grande propriedade acima de 50 hectares, em média. Essa classificação foi mantida até os dias atuais. Assim, não importando sua forma de uso, considerando a Lei n ${ }^{\circ}$ 8.629/93, art. $4^{\circ}$, a pequena propriedade é o imóvel rural com área de até quatro módulos fiscais; a média propriedade é o imóvel rural com área superior a 4 (quatro) e até 15 (quinze) módulos fiscais e, a partir de 15 (quinze) módulos, é considerada grande propriedade.

Para a realização da pesquisa na bacia hidrográfica do rio Pirapó, as atividades foram segmentadas em três etapas: a primeira foi sustentada em referências 
bibliográficas; a segunda envolveu o levantamento de dados agropecuários do Instituto Brasileiro de Geografia e Estatística (IBGE); e, por último, realizou-se o trabalho de campo e elaboraram-se os mapas temáticos.

Portanto, na primeira etapa, para a sustentação teórica relativa à estrutura geoecológica, bem como sobre a ocupação e o aspecto socioeconômico do compartimento arenítico, foi realizada uma revisão bibliográfica exploratória de livros, artigos, dissertações, teses e informações de órgãos oficiais por meio do site do ITCG (2010) e Paraná/Sema (2013).

Na segunda etapa, para obter informações sobre o número de estabelecimentos agropecuários, segundo as principais atividades econômicas do ano de 2006, foi consultado o sítio eletrônico do IBGE (2006).

$\mathrm{Na}$ terceira etapa, para a coleta de dados, foram aplicados questionários com os produtores rurais familiares pluriativos, em janeiro de 2016, para a realização da pesquisa da dissertação do mestrado. A escolha das propriedades para o estudo foi de modo que elas fossem representativas das características típicas de pequenos estabelecimentos pluriativos dentro do compartimento de paisagem analisado, pois neles são encontrados, com frequência, o uso do solo para a pastagem e, para complementar a renda, além da atividade agrícola, pratica-se a atividade não agrícola dentro e/ou fora de suas unidades. Sendo assim, foram entrevistados quatro produtores em quatro municípios pertencentes a essa unidade de paisagem: Colorado, Cruzeiro do Sul, Paranacity e Santa-Fé.

$\mathrm{Na}$ elaboração dos mapas temáticos, foram confeccionados os mapas para a realização de uma análise integrada dos atributos do meio físico. Para tanto, foram elaborados os seguintes mapas: localização da área de estudo; municípios pertencentes total ou parcialmente à bacia hidrográfica do rio Pirapó; e o compartimento arenítico contendo a altitude, declividade e classes de relevo, geologia e solos. Também se elaboraram mapas temáticos para cada propriedade cujo responsável foi entrevistado. Esses mapas contêm localização, classes de relevo, declividades, classes de solos e tipos de usos dos solos.

Para esta pesquisa sobre a pluriatividade, levou-se em conta a família rural. E para identificar os fatores que implicam no fenômeno da pluriatividade analisou-se o contexto regional e as características das unidades produtivas situadas no compartimento arenítico. 
Pois de acordo com Mattei (2007), as transformações estruturais do capitalismo agrário impactaram decisivamente sobre a forma tradicional de articulação das famílias com as unidades de produção. A nova forma de uso do solo para atender a demanda do mercado, exigiu das famílias novas estratégias de reprodução social. Nessa lógica, é que a família, principalmente, se impõe nas análises sobre a pluriatividade, como unidade mais relevante. De fato,

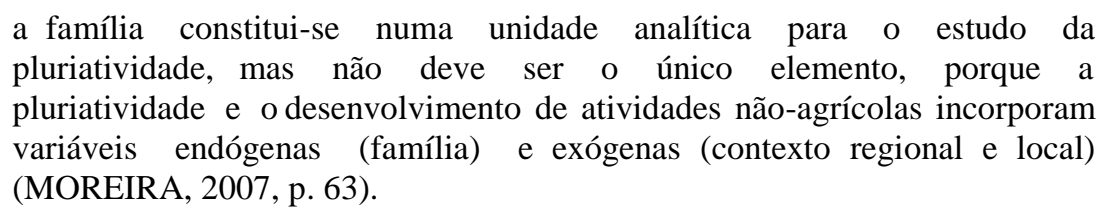
pluriatividade e o desenvolvimento de atividades não-agrícolas incorporam variáveis endógenas (família) e exógenas (contexto regional e local) (MOREIRA, 2007, p. 63).

\section{Características gerais da bacia hidrográfica do rio Pirapó e das propriedades pluriativas analisadas}

O compartimento arenítico situa-se no médio-baixo e baixo curso do Pirapó (Mapa 3). Dentre os compartimentos de paisagem da bacia, o compartimento arenítico foi o que apresentou as menores altitudes, com valores entre 256 e 691 m (Mapa 3 - A). A maior extensão espacial do relevo desse compartimento compreende altitudes abaixo de 500 m, elevando-se em direção ao setor leste e sudeste da bacia, onde há ocorrências de colinas que variam de amplas a médias, com topos largos, achatados e/ou arredondados, vertentes longas de declividades fracas, porém que se acentuam no terço inferior (NÓBREGA et al., 2015). As classes de relevos variam de plano (de 0 a 3\%) a forte ondulado (de 20 a 45\%), entretanto com o predomínio de relevo suave ondulado (de 3 a $8 \%$ ) (Mapa 3 - B).

A rocha predominante nesse compartimento de paisagem são os arenitos da Formação Caiuá, mas também se encontram, em menor ocorrência, os arenitos da Formação Adamantina, Santo Anastácio; basaltos da Formação Serra Geral e Aluviões recentes (Mapa 3 - C).

As classes de solos com maior representatividade no compartimento são os Latossolos Vermelhos e os Argissolos Vermelhos, ambos de textura média. Encontramse também, em menor representatividade, os Latossolos Vermelhos e os Nitossolos Vermelhos, ambos com textura argilosa a muito argilosa, oriundos da intemperização do basalto (Mapa 3 - D). 
Mapa 3: Compartimento arenítico; Altitude (A); Declividade e Classes de relevo (B); Geologia (C) e Solos (D)

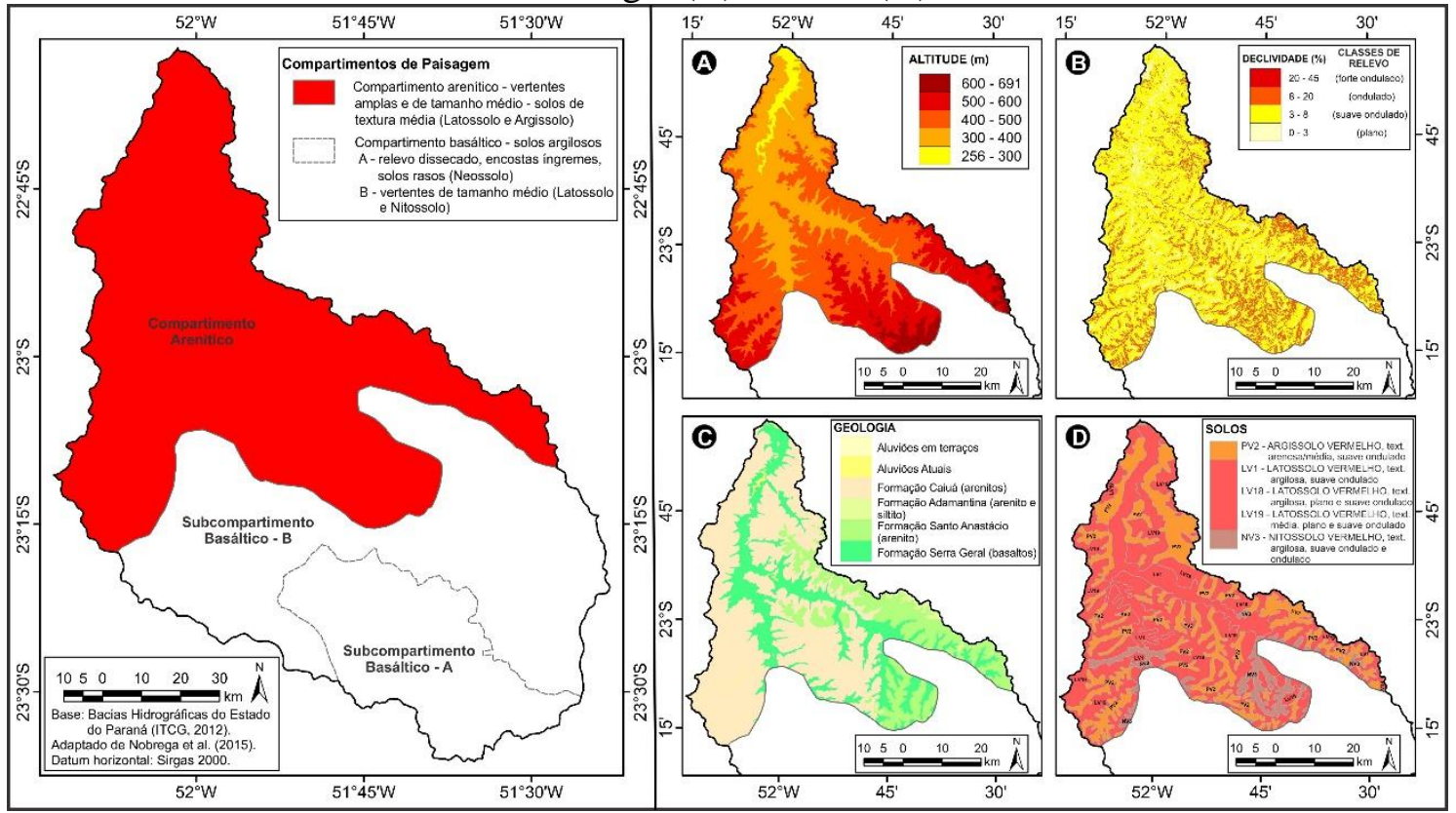

Fonte: Adaptado de Nóbrega et al., 2015. Elaborado pelos autores, 2020.

Nas propriedades 1, 3 e 4, verifica-se a existência dos Latossolos Vermelhos e dos Argissolos Vermelhos, ambos de textura média. Segundo Nakashima e Nóbrega (2003), os Latossolos Vermelhos de textura média ocupam, geralmente, o topo e a alta vertente, associados a relevos planos e suave ondulados, e foi o que ocorreu nessas propriedades. Em relação aos Argissolos, encontram-se em maior ocorrência se comparados aos Latossolos. Os Argissolos geralmente ocupam o terço inferior das encostas, normalmente associados a relevos suave ondulados e ondulados (FASOLO et al., 1988), e foi o que ocorreu nas propriedades 1, 3 e 4. Na propriedade 2, encontra-se apenas o Latossolo Vermelho de textura média, pois tal propriedade situa-se no topo de uma vertente e o seu relevo é de baixa declividade, sendo abaixo de $8 \%$.

Os Latossolos Vermelhos e Argissolos Vermelhos, ambos de textura média, são solos com uma suscetibilidade maior à erosão, principalmente os Argissolos. Mas ambos são naturalmente pobres em nutrientes e apresentam declividade média em torno de $8 \%$ (Quadro 1). Diante de suas características naturais, esses solos são mais propícios para culturas de cana-de-açúcar e pastagem. Essas culturas necessitam de extensas áreas para serem economicamente rentáveis. Esse fato, acaba forçando o pequeno produtor a praticar a pluriatividade para complementar a sua renda e possibilitar a sua permanência no campo. 
Nesse compartimento, o pequeno e o médio produtor diversificam as suas atividades e praticam a pluriatividade, diferentemente do grande produtor, que se dedica mais à monocultura em suas extensas áreas cultivadas.

Quadro 1: Características físicas das propriedades rurais pluriativas estudadas no compartimento arenítico

\begin{tabular}{|c|l|c|c|}
\hline $\begin{array}{c}\text { Propriedade/ } \\
\text { Município }\end{array}$ & \multicolumn{1}{|c|}{ Classes de Solos } & $\begin{array}{c}\text { Declividade } \\
\text { predominante } \\
\text { (\%) }\end{array}$ & $\begin{array}{c}\text { Classes de } \\
\text { relevo }\end{array}$ \\
\hline 1 - Colorado & $\begin{array}{l}\text { Argissolo Vermelho de textura média } \\
\text { e Latossolo Vermelho de textura } \\
\text { média. }\end{array}$ & $3-8$ & Suave ondulado \\
\hline $\begin{array}{c}\text { 2 - Cruzeiro } \\
\text { do Sul }\end{array}$ & $\begin{array}{l}\text { Latossolo Vermelho de textura } \\
\text { média. }\end{array}$ & $3-8$ & Suave ondulado \\
\hline 3 - Paranacity & $\begin{array}{l}\text { Argissolo Vermelho de textura média } \\
\text { e Latossolo Vermelho de textura } \\
\text { média. }\end{array}$ & $3-8$ & Suave ondulado \\
\hline 4 - Santa Fé & $\begin{array}{l}\text { Argissolo Vermelho de textura média } \\
\text { e Latossolo Vermelho de textura } \\
\text { média. }\end{array}$ & $3-8$ & Suave ondulado \\
\hline
\end{tabular}

Fonte: Pesquisa de campo, 2016.

Org.: Os autores, 2016.

Em relação à estrutura fundiária, todos os quatro estabelecimentos são de pequenas propriedades rurais, pois possuem 12ha, 1,2ha, 15,5ha e 32,5ha, respectivamente, como mostra o Quadro 2.

Não somente nas propriedades estudadas (Quadro 2), como também nesse compartimento de paisagem e na bacia do Pirapó, o predomínio é o da pequena propriedade. No Noroeste do Paraná, onde se situa esse compartimento arenítico, a pequena propriedade foi o modelo de colonização adotado pelas empresas colonizadoras privadas. A principal empresa colonizadora a atuar na região foi a Companhia de Terras Norte do Paraná (CTNP), posteriormente designada Companhia Melhoramentos Norte do Paraná (CMNP). Atualmente, apesar de o quadro estar se invertendo, ocorrendo a concentração fundiária, ainda se constata o predomínio dessa estrutura fundiária, o da pequena propriedade.

De acordo com dados do Censo Agropecuário de 2006, nos municípios (total ou parcialmente) pertencentes ao compartimento arenítico, dos 8.167 estabelecimentos agropecuários, 6.466 estão no estrato de menores de 50 ha. Diante disso, verifica-se que 
o perfil da estrutura fundiária desse setor da bacia do Pirapó é o das pequenas unidades produtivas.

Quadro 2: Características dos produtores e das propriedades rurais estudadas do compartimento arenítico

\begin{tabular}{|c|c|c|c|l|}
\hline Propriedade & $\begin{array}{c}\text { Classificação } \\
\text { da } \\
\text { propriedade }\end{array}$ & $\begin{array}{c}\text { Tamanho } \\
\text { (ha) }\end{array}$ & $\begin{array}{c}\text { Condição } \\
\text { do } \\
\text { produtor }\end{array}$ & \multicolumn{1}{|c|}{ Usos dos solos } \\
\hline 1 & Pequena & 12 & Proprietário & $\begin{array}{l}\text { Pastagem (gado de leite), } \\
\text { suinocultura, piscicultura, } \\
\text { hortaliças. }\end{array}$ \\
\hline 2 & Pequena & 1,2 & Proprietário & $\begin{array}{l}\text { Pastagem (gado leiteiro), } \\
\text { laticínio (produção de } \\
\text { requeijão, queijo e } \\
\text { muçarela). }\end{array}$ \\
\hline 3 & Pequena & 15,5 & Proprietário & $\begin{array}{l}\text { Pastagem (gado leiteiro e de } \\
\text { corte). }\end{array}$ \\
\hline 4 & Pequena & 32,5 & Proprietário & $\begin{array}{l}\text { Pastagem (gado de corte), } \\
\text { granja (frango caipira e } \\
\text { suíno caipira) e de árvores } \\
\text { frutíferas (laranja). }\end{array}$ \\
\hline
\end{tabular}

Fonte: Pesquisa de campo, 2016.

Org.: Os autores, 2016.

Em relação à condição do produtor ao utilizar a terra, esta se refere ao tipo de pessoa que cultiva a terra, ou seja, se é proprietário, arrendatário, parceiro, ocupante, entre outros. Trata-se do regime de exploração. No compartimento arenítico, o predomínio de quem cultiva a terra é o do proprietário. Dos 8.167 estabelecimentos agropecuários (total ou parcialmente) existentes nesse setor da bacia hidrográfica, 7.135 unidades são cultivadas pelos seus proprietários, 619 unidades pelos arrendatários, 188 por parceiros, e os outros 225 estabelecimentos restantes são cultivados por ocupantes de terras, entre outros, conforme informações obtidas no Censo Agropecuário 2006. De acordo com o Quadro 2, o predomínio de quem cultiva a terra nas propriedades estudadas também é o do proprietário, pois as quatro propriedades estudadas são cultivadas pelos próprios proprietários.

O Quadro 2 mostra que, na propriedade 1, o uso foi principalmente destinado à pastagem (gado de leite) e, secundariamente, à horticultura, piscicultura e barracões com criações de suínos. Na propriedade 2, o predomínio do uso do solo foi o da pastagem e, em segundo plano, da agroindústria de laticínios (queijo, requeijão e muçarela). Na 
propriedade 3, predomina a pastagem destinada à criação de gado de leite e de corte. E, na propriedade 4, o predomínio do uso do solo foi o da pastagem (gado de corte) e, em menor extensão, encontram-se diferentes usos da terra, tais como: a criação de frango caipira e suínos (de corte) e plantação de laranja (Quadro 2). Diante disso, verifica-se que o principal uso do solo nas propriedades estudadas consiste na pastagem.

Tabela 1: Número de estabelecimentos agropecuários, segundo as principais atividades econômicas (2006)

\begin{tabular}{|c|c|c|c|c|}
\hline Município & $\begin{array}{c}\text { Lavoura } \\
\text { Temporária }\end{array}$ & $\begin{array}{c}\text { Lavoura } \\
\text { Permanente }\end{array}$ & $\begin{array}{c}\text { Pecuária e } \\
\text { criação de } \\
\text { outros animais }\end{array}$ & Total \\
\hline & Estabelecimento & Estabelecimento & Estabelecimento & Estabelecimento \\
\hline Ângulo & 115 & 19 & 89 & 223 \\
\hline Astorga & 339 & 202 & 506 & 1.047 \\
\hline Atalaia & 138 & 39 & 172 & 349 \\
\hline Colorado & 43 & 87 & 400 & 530 \\
\hline Cruzeiro do Sul & 84 & 92 & 203 & 379 \\
\hline Flórida & 76 & 15 & 101 & 192 \\
\hline Guaraci & 31 & 29 & 195 & 255 \\
\hline Iguaraçu & 113 & 35 & 88 & 236 \\
\hline Itaguajé & 33 & 25 & 311 & 369 \\
\hline Jaguapitã & 81 & 56 & 312 & 449 \\
\hline Jardim Olinda & 14 & 22 & 38 & 74 \\
\hline Lobato & 95 & 9 & 131 & 235 \\
\hline $\begin{array}{l}\text { Mandaguaçu } \\
\text { Munhoz de }\end{array}$ & 247 & 87 & 240 & 574 \\
\hline Mello & 81 & 79 & 172 & 332 \\
\hline $\begin{array}{l}\text { Nossa Senhora } \\
\text { das Graças }\end{array}$ & 85 & 59 & 229 & 373 \\
\hline Nova Esperança & 102 & 82 & 595 & 779 \\
\hline Paranacity & 82 & 60 & 170 & 312 \\
\hline $\begin{array}{l}\text { Paranapoema } \\
\text { Presidente }\end{array}$ & 11 & 1 & 21 & 33 \\
\hline Castelo Branco & 70 & 41 & 142 & 253 \\
\hline Santa Fé & 147 & 85 & 234 & 466 \\
\hline Santa Inês & 22 & 12 & 88 & 122 \\
\hline Uniflor & 55 & 32 & 124 & 211 \\
\hline Total & 2.064 & 1.168 & 4.561 & 7.793 \\
\hline
\end{tabular}

Fonte: IBGE - Censo Agropecuário, 2006

Org.: Os autores, 2016. 
A Tabela 1 também mostra que o predomínio do uso da terra desse compartimento arenítico é o de municípios com números de estabelecimentos e áreas destinadas à pecuária e à criação de outros animais.

Dos 7.793 estabelecimentos desse compartimento de paisagem, onde se encontram as principais atividades econômicas, que são a lavoura temporária, a lavoura permanente e a pecuária e criação de outros animais, observa-se que a pecuária e a criação de outros animais são significativas, pois foram encontradas em 4.561 unidades. A lavoura temporária foi encontrada em 2.064 estabelecimentos e a lavoura permanente em 1.168 estabelecimentos (Tabela 1 ).

De acordo com os dados observados nos levantamentos em campo (Quadro 2), em estudos realizados por Nóbrega et al. (2015) e no Censo Agropecuário de 2006, a maioria dos municípios pertencentes a esse setor da bacia do Pirapó tem o maior número de estabelecimentos destinados à pastagem e criação de outros animais (ovinos, equinos, entre outros), seguido pelo cultivo da cana-de-açúcar (considerada como lavoura temporária), a qual está gradativamente ocupando o espaço da pastagem. Segundo Nóbrega e Serra (2009), isso ocorre devido à rentabilidade dessa cultura e à implantação de usinas de açúcar e álcool na região, favorecendo, assim, o seu avanço.

Para Castro Filho (1999), toda a gleba de terra apresenta uma potencialidade de uso de acordo com os seus atributos edafoclimáticos. Assim, o predomínio da pastagem e da cana-de-açúcar, nesse setor da bacia, justifica-se em função do potencial pedológico, pois essas culturas se adaptam a solos derivados das rochas areníticas com reduzida fertilidade natural.

\section{Análise das propriedades estudadas}

Nas quatro propriedades familiares pluriativas em estudo, as quais são representativas da referida unidade de paisagem, o uso dos solos foi principalmente para a pastagem destinada à criação de gado de corte e/ou de leite. Em virtude de essa atividade ser mais rentável em extensa área, que não é o caso dessas propriedades em estudo, diante disso, como estratégias de reprodução social e econômica, esses produtores familiares 
praticam a pluriatividade. Isso porque suas pequenas dimensões de área e o pouco capital disponível, não dão subsistência aos seus proprietários.

Assim, além de suas atividades de criação de gado de corte e/ou de leite, praticam atividades não agrícolas, que geralmente estão relacionadas aos seus produtos agropecuários, como é o caso da agroindústria familiar de embutidos de pequenos animais e da agroindústria de laticínios (queijo, requeijão e muçarela). Portanto, pluriatividade associada à essa exploração. É o que pode ser verificado a seguir.

A propriedade 1 situa-se no município de Colorado (Mapa 4). O relevo é predominantemente suave ondulado (3-8\%) (Mapa 4 - B). Nesse setor da bacia do Pirapó, o predomínio é o de relevos de baixa declividade, como é o caso dessa propriedade. Possui duas classes de solo, o Latossolo Vermelho de textura média em relevo plano e suave ondulado e o Argissolo Vermelho de textura média em relevo suave ondulado e ondulado (Mapa 4 - C), os quais são dois tipos de solos predominantes nessa unidade de paisagem.

Diante desses atributos naturais, a sua dimensão de área total de 12 ha tem como principal uso a pastagem destinada à criação de gado leiteiro (Mapa 4 - D). Secundariamente, há usos diversificados: hortaliças, piscicultura e suinocultura. O proprietário possui essa propriedade há menos de um ano, e ainda não apresenta muita experiência nas atividades agropecuárias. A intenção do proprietário é dinamizar a sua produção, ou seja, praticar a pluriatividade para melhorar a renda dessa propriedade. $\mathrm{O}$ seu projeto é montar uma leiteria; uma agroindústria com produtos derivados de leite, inicialmente, o queijo; vender as hortaliças em feira; e pretende montar um abatedouro para suinocultura. 


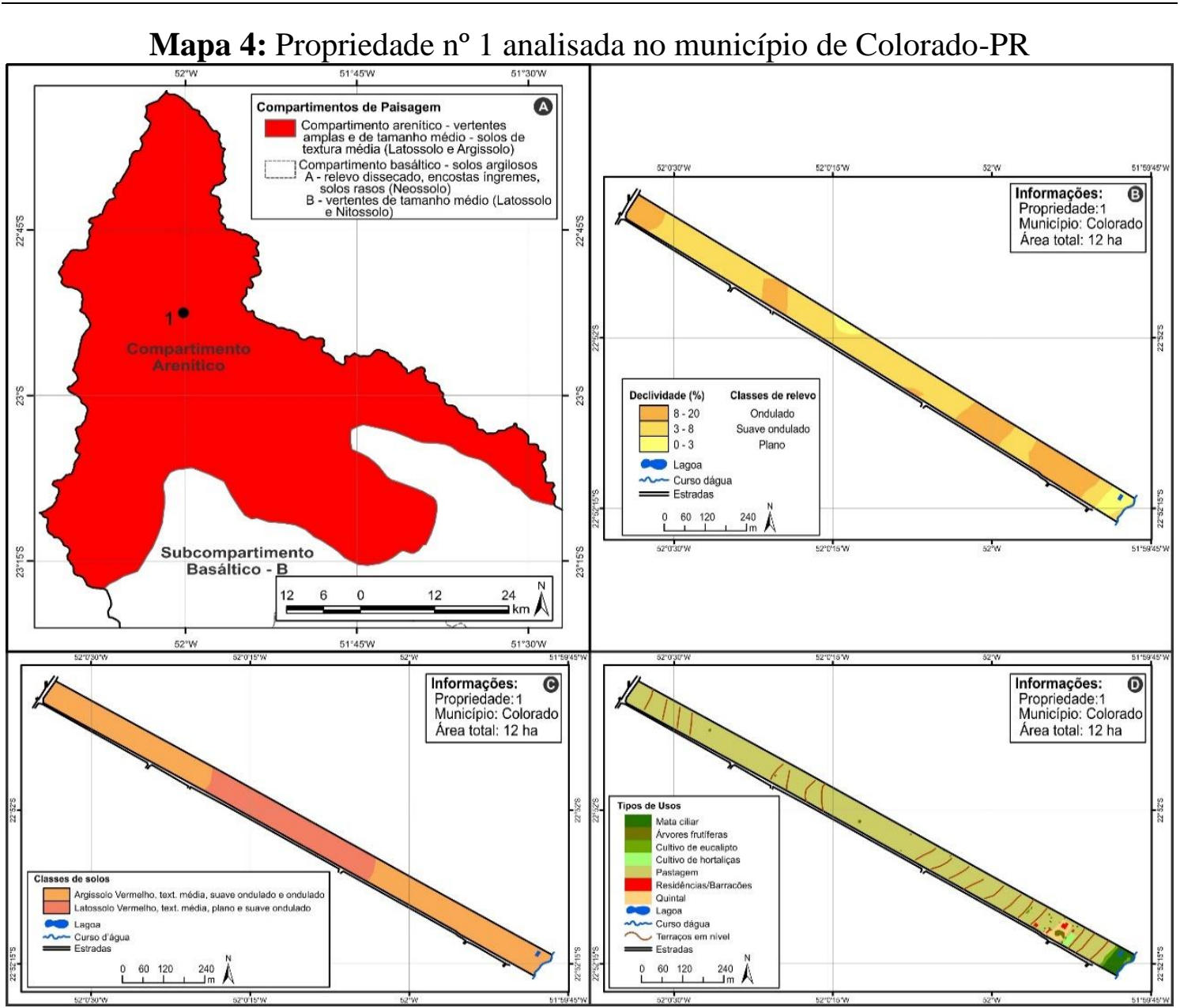

Fonte: Elaborado pelos autores, 2016.

De acordo com o produtor, ele adquiriu o seu rebanho de bovinos leiteiros no município de Lapa - PR, considerada uma região de criação de raças com grande tradição da produção de leite, mas o que ele não sabia é que esses animais necessitavam de sombra na propriedade, principalmente nesse setor da bacia, que apresenta a temperatura mais elevada do estado, muito diferente da região de clima temperado onde esses animais foram adquiridos. Por falta de sombra, muitos desses animais desenvolveram o câncer de pele. Porém, o pecuarista que comercializou esses animais com esse produtor se propôs a realizar troca por outras raças de bovinos leiteiros com uma genética adequada para as condições climáticas desse compartimento arenítico, mas considerando um valor abaixo do que esse produtor pagou por cada animal, pois ele comprou por $\mathrm{R} \$ 2.500,00$ e repassou para o pecuarista por $\mathrm{R} \$ 1.800,00$ reais. Portanto, o produtor já vem levando prejuízo desde o início de sua produção nessa propriedade rural. 
O produtor reclamou que vem apresentando dificuldades ao iniciar a sua atividade agropecuária, por falta de apoio técnico e financiamento para compra de materiais agrícolas e que, no momento, está necessitando adquirir um pequeno trator para facilitar o cultivo da horta e um veículo utilitário para transportar as verduras até a feira. Ele não consegue financiamento pelo Programa Nacional de Fortalecimento da Agricultura Familiar (Pronaf), porque precisa apresentar a Declaração de Aptidão ao Pronaf (DAP) e, para isso, necessita de, no mínimo, um ano de atividade na propriedade rural. Diante disso, verifica-se que a agricultura familiar necessita de amparo institucional que possibilite a sua produção, desde assistência técnica ao financiamento, principalmente no início da atividade rural.

A falta de financiamento agrícola dificulta a continuidade de tais atividades, tendo em vista a dificuldade de compra de maquinários e de insumos para a produção. A falta de financiamentos para subsidiar a produção é um dos fatores que facilita o avanço da cana-de-açúcar sobre essa região, considerando que o pequeno proprietário não consegue subsídios para a sua produção, acaba cedendo suas terras, seja por arrendamento ou venda, para os arrendatários ou para os grandes proprietários fundiários para a produção da cana-de-açúcar.

A propriedade 2 situa-se no município de Cruzeiro do Sul (Mapa 5). O seu relevo é de baixa declividade, com valores inferiores a 8\% (Mapa 5 - B), pois situa-se no topo de uma vertente. Em função da sua topografia pouco movimentada, o solo dessa propriedade é o Latossolo Vermelho de textura média (Mapa 5 - C). Os Latossolos são solos pouco suscetíveis à erosão devido à sua grande profundidade, boa permeabilidade e à posição topográfica que ocupam. Porém, de acordo com Fasolo et al. (1988), os Latossolos da região Noroeste do Paraná, formados a partir da alteração dos arenitos (Formações Caiuá, Santo Anastácio e Adamantina), apresentam significativos teores de areia que, combinados ao uso inadequado do solo, têm ocasionado processos erosivos de diferentes intensidades. Diante dessas características naturais, o uso do solo dessa propriedade é voltado para a pastagem e a criação de gado leiteiro. Para complementar a renda da propriedade, o proprietário trabalha com a agroindústria familiar, produzindo produtos derivados de leite, tais como: requeijão, queijo nozinho, muçarela e queijo caipira. 
Pluriatividade na agricultura familiar no compartimento arenítico da bacia hidrográfica do Rio Pirapó - Paraná/Brasil
Tsugie Kawano

Hélio Silveira

Elpídio Serra

Carlos Henrique da Graça

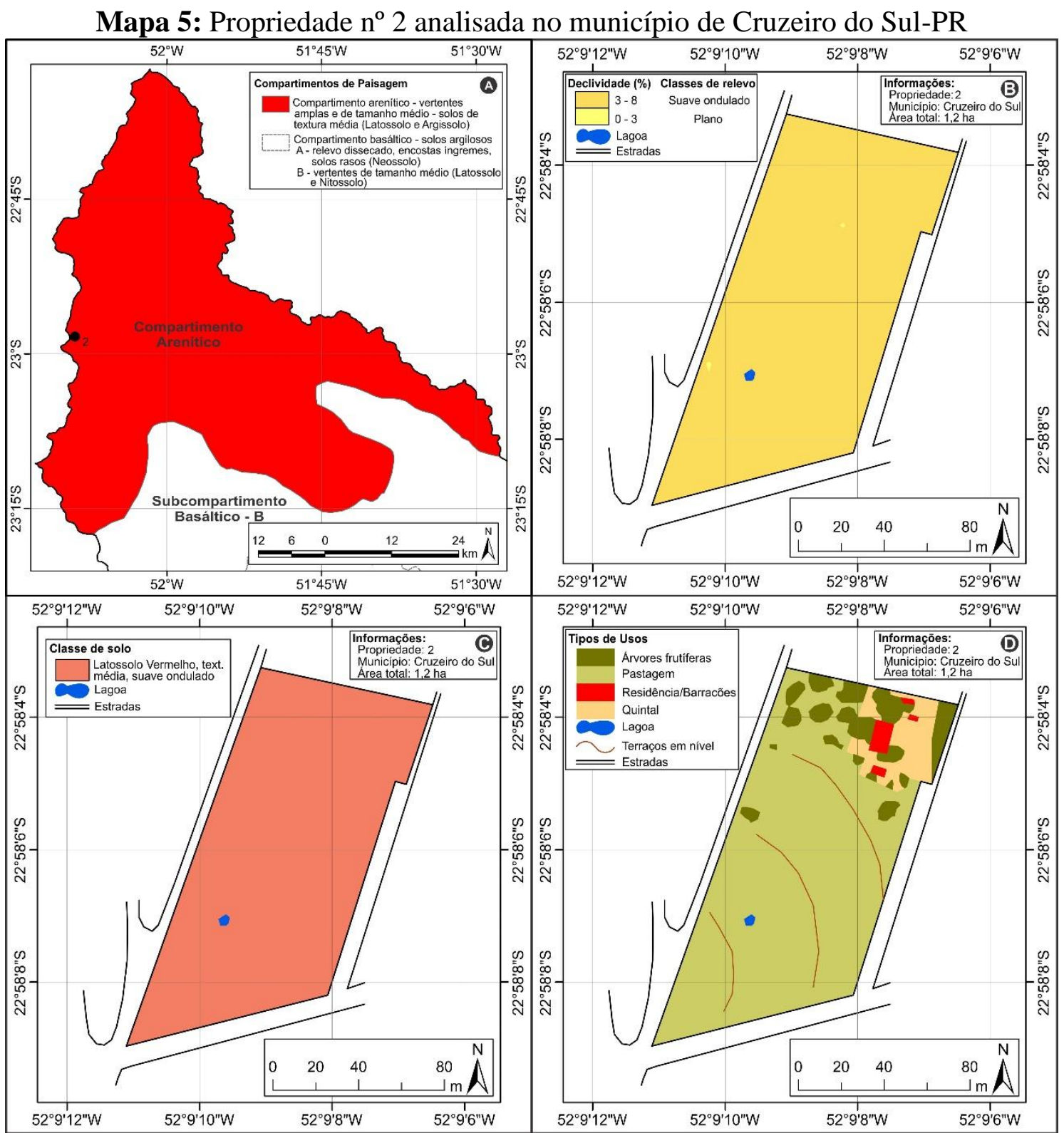

Fonte: Elaborado pelos autores, 2016.

Nessa propriedade, que foi adquirida em 1996, reside um casal e seu filho de 24 anos de idade e sua esposa, que trabalha na cidade. $\mathrm{O}$ proprietário trabalhava como empregado em propriedades rurais vizinhas à sua propriedade. Segundo o produtor, os recursos para a compra dessa pequena propriedade rural de 1,2 ha foi a junção de uma reserva de dinheiro que acumulava há algum tempo e outra parte foi uma moto e um carro usados, que também entraram no negócio no momento da compra do imóvel. De início, havia somente a pastagem; com o tempo, foram construindo as estruturas, ou seja, 
barracão para a atividade de agroindústria de laticínios. Portanto, nessa unidade familiar, encontra-se o fenômeno da pluriatividade, pois a nora do produtor rural trabalha fora dessa unidade para complementar a renda da família e, dentro da propriedade, o restante da família exerce atividades não agrícolas - a agroindústria familiar.

Há autores, como é o caso de Schneider (2009), que consideram a pequena agroindústria como atividade para-agrícola. Segundo o autor, a atividade para-agrícola é um conjunto de procedimentos que implicam a transformação, o beneficiamento e/ou processamento de produção agrícola in natura ou de derivados produzidos dentro de um estabelecimento ou adquiridos em parte ou no todo fora. Schneider (2003) cita, como exemplo, o caso de um agricultor que beneficia sua produção de erva-mate e a vende em pacotes avulsos, ou então famílias rurais que produzem doces coloniais ou derivados de leite, como o queijo. Segundo Escher,

\begin{abstract}
As atividades para-agrícolas se expandem à medida que a produção de produtos para autoconsumo e subsistência da família (derivados de leite, cana, carnes, frutas e outros) passa a ser destinada à venda, crescendo e começando a ocupar espaços fora do âmbito doméstico e a tornar-se uma atividade independente de transformação de alimentos, inaugurando uma nova jornada de trabalho, rotinas diferenciadas e novas ocupações que, combinadas com a agricultura como atividade principal, gera a pluriatividade. No Brasil, estes empreendimentos vêm sendo chamados de "agroindústrias rurais familiares", quase sempre de pequeno porte (mas com escalas variáveis) e organizados em uma diversidade de formas (individuais, cooperativas, associações, redes) (ESCHER, 2014, p. 654-655).
\end{abstract}

Como a principal atividade econômica desse setor da bacia é a pastagem, que possui uma presença significativa destinada à criação de gado leiteiro, é comum a existência da agroindústria no ramo de laticínios, como é o caso dessa propriedade.

O produtor possui financiamento pelo Pronaf e contou com a orientação do Serviço Brasileiro de Apoio às Micro e Pequenas Empresas (SEBRAE), participa de sua associação, onde aprendeu a se adequar às normas do seu produto no mercado, como, por exemplo, o uso de código de barra nos seus produtos.

Essa propriedade, em virtude do seu tamanho (1,2 ha), possui somente 12 cabeças de gado leiteiro, portanto o leite é insuficiente para a produção de sua agroindústria; diante disso, o produtor compra leite de outros pecuaristas. A sua produção é comercializada em supermercados dos municípios de Cruzeiro do Sul e Paranacity. De acordo com o 
produtor entrevistado, a pequena extensão de área dessa propriedade é o suficiente para essa atividade, não há necessidade de ser grande a área, pois caso aumentar a área e a produtividade; para isso, necessitaria de mais mão de obra e, no momento, não tem condições para isso.

Kautsky (1980), em sua pesquisa realizada na Alemanha, observou que as explorações agrícolas com menos de 2 hectares são em geral muito pequenas; com isso, não dão subsistência aos seus proprietários. Diante disso, eles se veem forçados a trabalhar como assalariados ou submeter-se a uma ocupação paralela. Mas todo esse fator depende também do rendimento do solo, se este é mais ou menos produtivo.

De acordo com Kautsky (1980), as atividades rurais não agrícolas aparecem na literatura internacional como trabalho acessório. O autor afirma que são vários os tipos de trabalhos acessórios ao alcance dos pequenos camponeses, dentre eles, tem-se a ocupação em indústrias em domicílio, que, em geral, se desenvolvem em regiões de pouca aptidão agrícola com solos pobres (que é o caso dessa propriedade 2). Embora menos eficiente, a indústria no domicílio rural, se comparada com a grande indústria urbana, desfruta da vantagem de se apoiar na agricultura, o que lhe permite rebaixar os custos de produção, especialmente com a remuneração da força de trabalho.

A propriedade 3 possui uma área total de 15,5 ha. Situa-se no município de Paranacity (Mapa 6). Possui o relevo predominantemente de baixa declividade (3-8\%) e nela se encontram dois tipos de solos: o Argissolo Vermelho e o Latossolo Vermelho, ambos de textura média. Diante dessas características naturais, o uso do solo é exclusivamente para a pastagem destinada ao gado de leite e de corte (Mapa 6 - B, 6 - C e 6 - D). E, para complementar a renda, um dos membros da família desempenha uma atividade não agrícola fora da propriedade, pois a esposa do proprietário dessa unidade rural trabalha no cartório do município de Paranacity.

O produtor relata que faz nove anos que possui essa propriedade, que está desanimado em seguir trabalhando na atividade de criação de gado, que tem a intenção de vender. Ele deixou a sua atividade de leiteria por falta de capital e não está conseguindo renovar o Pronaf, que é um programa de apoio ao agricultor familiar, disponibilizado pelo governo federal. 


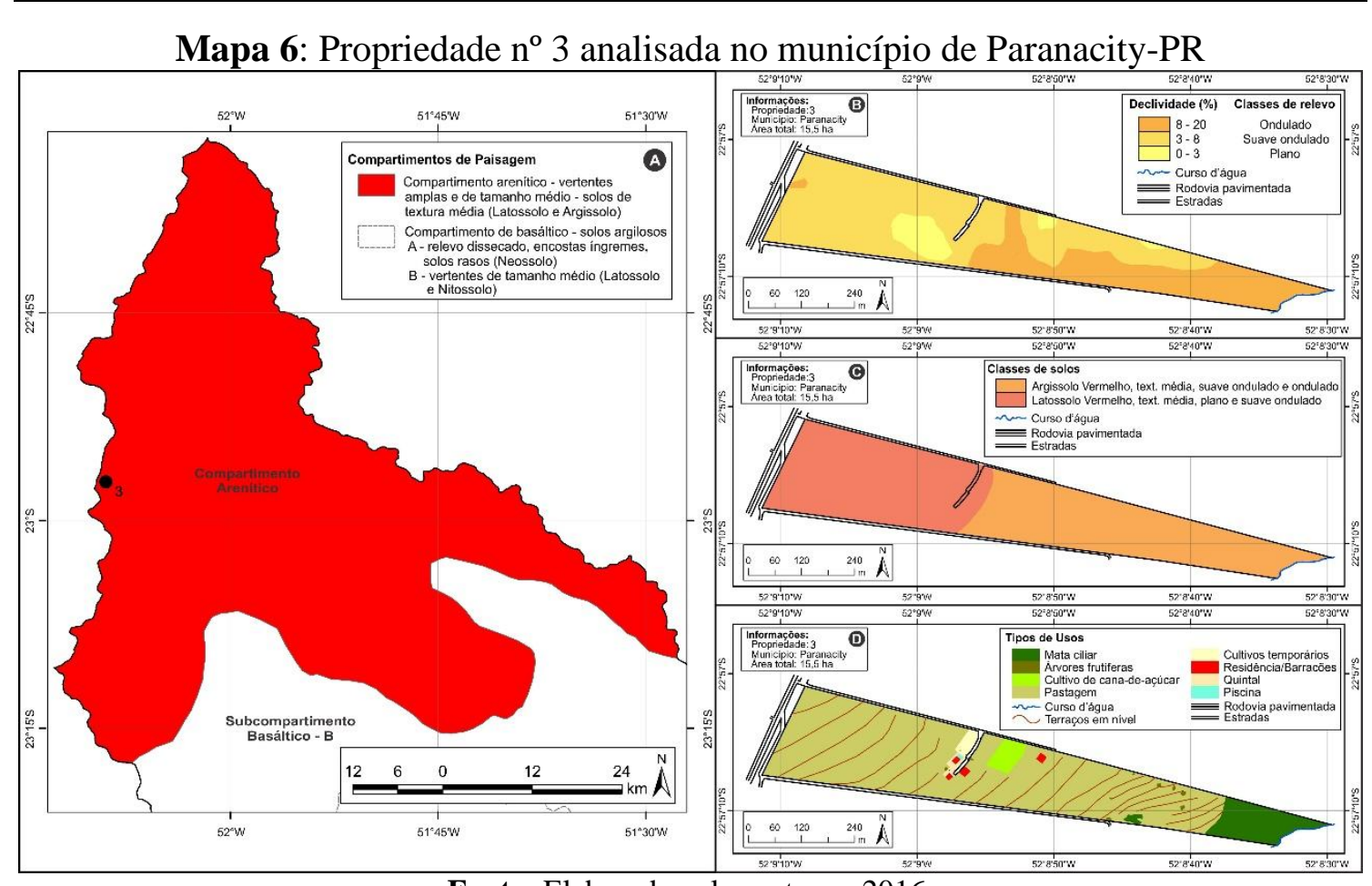

Fonte: Elaborado pelos autores, 2016.

Utilizou o financiamento desse programa do governo durante oito anos, mas agora já venceu e não está conseguindo renovar, pois tem a tal da DAP, que é uma documentação que é analisada, e pelo fato de ele ainda não ter o seu casamento registrado em cartório, não estão permitindo a renovação do Pronaf. Com isso, o produtor não tem capital para investir em sua propriedade. Outro fator que o desanima são os roubos de gado bovino que estão ocorrendo ultimamente no município de Paranacity e região. Assim, pretende se mudar para Mato Grosso do Sul, mas continuar a trabalhar com a mesma atividade, ou seja, pecuária.

A propriedade 4 localiza-se no município de Santa Fé, apresenta uma área total de 32,5 ha, é considerada como pequena propriedade. Possui o predomínio do relevo suave ondulado (Mapa 7 - B). Ao longo dessa propriedade, foram identificados dois tipos de solos: o Latossolo Vermelho de textura média, que se encontra no topo em relevo plano e suave ondulado, e o Argissolo Vermelho de textura média, que se estende desde a média até a baixa vertente, onde o relevo varia de ondulado a plano (Mapa 7 - C).

Em relação aos Argissolos, geralmente ocupam o médio e o baixo setor da vertente, associados a relevos suave ondulados e ondulados, como ocorreu nessa propriedade. O gradiente textural entre o horizonte $\mathrm{A}$ e $\mathrm{Bt}$, associado aos reduzidos teores 
Pluriatividade na agricultura familiar no compartimento

Tsugie Kawano arenítico da bacia hidrográfica do Rio Pirapó - Paraná/Brasil

Hélio Silveira

Elpídio Serra

Carlos Henrique da Graça

de argila e de matéria orgânica e à posição que ocupam na vertente, tornam os Argissolos altamente suscetíveis à erosão (FASOLO et al., 1988).

Mapa 7: Propriedade $n^{\circ} 4$ analisada no município de Santa Fé-PR

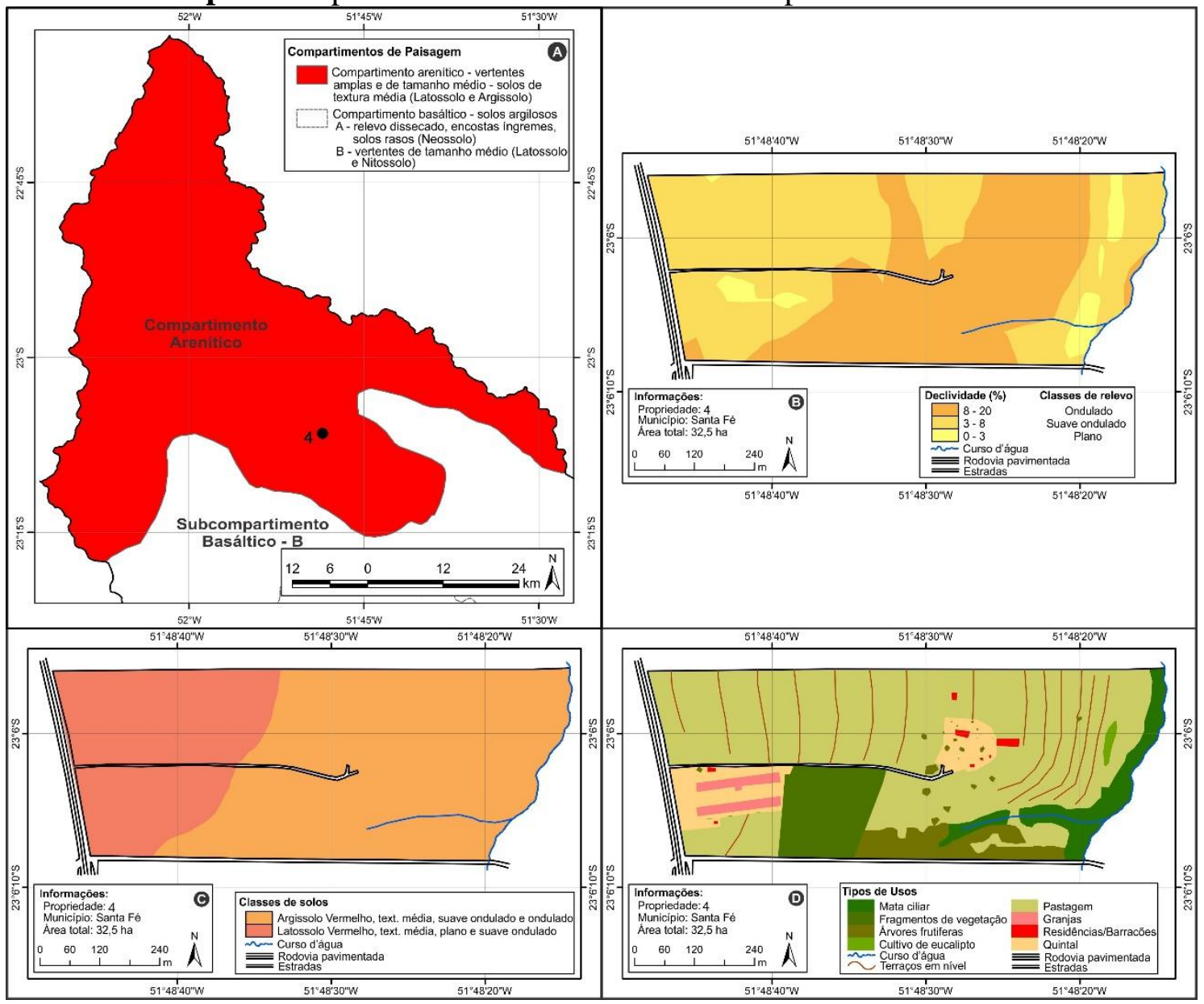

Fonte: Elaborado pelos autores, 2016.

Em função de sua característica física natural, sua principal atividade é a pecuária de corte: são 24 hectares destinados à pecuária, com 150 cabeças de gado (Mapa 7 - D). O restante é floresta legal, criação de suínos e de frango caipira, e produção de fruticultura, com o cultivo de abacaxi, uva, poncã e laranja (Mapa 7 - D), os quais são comercializados em supermercados e diretamente com o consumidor final em sua propriedade. O produtor comercializa o gado com o frigorífico, e a criação de leitoa caipira e do frango caipira é inspecionada pela prefeitura municipal, para permanecer com a licença de abate desses animais da propriedade e a comercialização na propriedade. Outra atividade que o produtor realiza é a produção e comercialização do feno que é 
produzido na sua propriedade. Feno é um capim desidratado e prensado, que serve para alimentar o gado em época de escassez do pasto. O produtor comercializa os fardos de feno até fora do Brasil.

Essa propriedade destaca-se pela pluriatividade. Segundo o produtor, suas atividades diversificadas acompanham a tendência de mercado. Alentejano (2001) destaca a dificuldade crescente para que os pequenos agricultores sobrevivam apenas da produção agrícola, sendo empurrados, cada vez mais, em direção à pluriatividade.

De acordo com o produtor, para a realização de suas atividades agrícolas e não agrícolas, ele conseguiu a compra de um trator pelo Pronaf, o trator solidário, que foi um benefício realizado pelo governo do Paraná. Em relação à assistência técnica, ele conta com a Emater do município de Santa Fé, que, segundo ele, atende muito bem os agropecuaristas.

Quem mora nessa propriedade é o proprietário, a sua esposa e seus dois filhos. A sua esposa e o filho mais velho trabalham fora da propriedade. Ela trabalha como professora concursada pelo estado do Paraná na disciplina de Física, no município de Santa Fé, e o filho na área de Engenharia Civil. Mas nas horas ociosas, ambos ajudam nos afazeres da propriedade. Portanto, trabalham nessa propriedade, o proprietário e sua família. E quando necessário, contrata pessoas para trabalhar por diária na propriedade.

Pode-se observar que esse proprietário é uma pessoa empreendedora, pois além das atividades agropecuárias e não agrícolas citadas anteriormente, o produtor está construindo, na cabeceira desse estabelecimento, uma lanchonete em estilo colonial, pois segundo ele, há um bom fluxo de veículos nessa rodovia que passa pela cabeceira de sua propriedade e pode se tornar uma boa fonte de comercialização dos seus produtos. Também pretende trabalhar com o turismo rural. Portanto, verifica-se que mesmo a unidade de produção agrícola situada em áreas desfavoráveis à agricultura, com solos pobres em nutrientes como no caso desse compartimento arenítico, há produtor rural que, através da pluriatividade, consegue obter sucesso em seu empreendimento.

Portanto, a propriedade 4 é um exemplo de propriedade com uso do solo diversificado e nela se encontra a presença da pluriatividade. De acordo com Blum (2001), são nas propriedades familiares que se encontram mais diversificações, e os principais alimentos que estão diariamente em nossa mesa, geralmente, são produzidos nas propriedades com menos de 100 ha. 


\section{Considerações finais}

A pesquisa mostrou que o principal tipo de uso do solo é a pastagem plantada, destinada à criação de gado de corte e de leite, seguida pelo cultivo da cana-de-açúcar. Essas culturas se adaptam bem aos Argissolos Vermelhos e os Latossolos Vermelhos, ambos de textura média, os quais possuem baixa resistência à erosão, são pobres em elementos químicos e facilmente degradados em função do uso inadequado do solo.

Constatou-se em campo que, nas quatro propriedades familiares pluriativas em estudo, o uso dos solos foi principalmente para a pastagem destinada à criação de gado de corte e de leite. Além dessas atividades, praticam-se atividades não agrícolas, que geralmente estão articuladas aos produtos agropecuários, como é o caso da agroindústria familiar de embutidos de pequenos animais e da agroindústria de laticínios (queijo, requeijão e muçarela). A propriedade 4 se diferencia um pouco das demais, pois uma de suas atividades é a produção de feno para a comercialização.

Portanto, a pesquisa demonstrou que as características do meio físico encontradas nas propriedades rurais analisadas também influenciam na presença da pluriatividade, visto que, nesse compartimento arenítico, a atual atividade economicamente rentável e predominante é a pastagem, seguida da cana-de-açúcar, que são lucrativas quando se cultivam em extensas áreas, e que demandam grandes investimentos na correção, adubação e no controle do solo da erosão. Diante das dificuldades dos agricultores familiares que não se dispõem de extensas áreas e capital, buscam na pluriatividade a possibilidade de sua reprodução econômica e social.

Dos quatro produtores entrevistados, dois reclamaram ter dificuldades em adquirir acesso ao Pronaf, devido à burocracia, principalmente para os pequenos produtores rurais. Porém, os outros dois entrevistados declararam que foi graças ao Pronaf que conseguiram o financiamento para a compra de máquinas agrícolas e de veículos para transportar os seus produtos, contribuindo, assim, para melhorar a qualidade de suas vidas no campo. Portanto, é necessário que a agricultura familiar receba um amparo institucional que lhe possibilite a sua reprodução e que seja menos burocrático o acesso dos pequenos produtores às políticas públicas. 


\section{Agradecimentos}

Agradecemos à Coordenação de Aperfeiçoamento de Pessoal de Nível Superior (Capes) pelo apoio e fomento, e aos produtores rurais que participaram das entrevistas.

\section{REFERÊNCIAS}

ABRAMOVAY, Ricardo. O futuro das regiões rurais. 1.ed. Porto Alegre: Editora da UFRGS, 2003.

ALENTEJANO, Paulo Roberto Raposo. Pluriatividade: uma noção válida para a análise da realidade agrária brasileira? In: TEDESCO, João Carlos (Org.). Agricultura

familiar: Realidades e perspectivas. 3. ed. Passo Fundo: ed. UPF, 2001. p. 149 - 175.

ANJOS, Flávio Sacco dos. Pluriatividade e desenvolvimento rural no Sul do Brasil. Cadernos de Ciência \& Tecnologia, Brasília, v. 20, n. 1, p. 11-44, jan./abr. 2003.

BERTRAND, Claude; BERTRAND, Georges. O geossistema: um espaço-tempo antropizado. In: BERTRAND, Georges; BERTRAND, Claude. Uma geografia transversal e de travessias: o meio ambiente através dos territórios e das temporalidades. Georges e Claude Bertrand; organizador Messias Modesto dos Passos. Maringá: Massoni, 2009, p. 307-314.

BIGARELLA, João José; MAZUCHOWSKI, Jorge. Z. Visão integrada da problemática da erosão. Curitiba, Associação de Defesa e Educação Ambiental e Associação Brasileira de Geologia de Engenharia, 1985.

BLUM, Rubens. Agricultura familiar: Estudo preliminar da definição, classificação e problemática. In: TEDESCO, João Carlos (Org.) Agricultura familiar: realidades e perspectivas. 3. ed. Passo Fundo: UPF, 2001. cap. 2. p. 57-106.

BRASIL. Lei n. 8.629, de 25 de fevereiro de 1993. Dispõe sobre a regulamentação dos dispositivos constitucionais relativos à reforma agrária, previstos no Capítulo III, Título VII, da Constituição Federal. Diário Oficial da União, Brasília, DF, 26 fev. 1993. Disponível em: http://www.planalto.gov.br/ccivil_03/leis/L8629.htm. Acesso em: 06 fev. 2017.

CANCIAN, Nadir Aparecida. Cafeicultura paranaense: 1900-1970. 1977. 497 f. Tese (Doutorado)-Programa de Pós-graduação em História, Universidade de São Paulo, São Paulo, 1977.

CARNEIRO, Maria José. Camponeses, agricultores e pluriatividade. Rio de Janeiro: Contra Capa Editora, 1998. 
CASTRO FILHO, Celso de Castro. Uso potencial do solo. In: Celso de Castro Filho; Osmar Muzilli (Org.). Uso e manejo dos solos de baixa aptidão agrícola. Londrina, IAPAR, 1999, v. 2, p.12-17.

CMNP (Companhia Melhoramentos Norte do Paraná). Colonização e desenvolvimento do Norte do Paraná. São Paulo, 1975. (Publicação Comemorativa dos 50 anos da CMNP).

ESCHER, Fabiano. et al. Caracterização da Pluriatividade e dos Plurirrendimentos da Agricultura Brasileira a partir do Censo Agropecuário. Revista de Economia e Sociologia Rural- RESR. Piracicaba, SP, v.52, n. 04, p. 643-668, out./dez. 2014.

FASOLO, Pedro Jorge et al. Erosão: Inventário de áreas críticas no Noroeste do Paraná. Boletim Técnico no 23. Londrina: IAPAR,1988.

FLEISCHFRESSER, Vanessa. Modernização Tecnológica da Agricultura contrastes regionais e diferenciação social no Paraná da década de 70. Curitiba: Liv. Chain: CONCITEC/IPARDES, 1988.

IBGE (Instituto Brasileiro de Geografia e Estatística). Censo Agropecuário de 2006. Disponível em: https://sidra.ibge.gov.br/home/cnt/brasil. Acesso em: 26 maio 2016.

ITCG. Produtos Cartográficos. 2010. Disponível em: http://www.itcg.pr.gov.br/modules/conteudo/conteudo.php?conteudo=47. Acesso em: 3 jan. 2016.

KAUTSKY, Karl. A questão agrária. 3 ed. São Paulo: Proposta Editorial, 1980.

MATTEI, Lauro. Relevância da família como unidade de análise nos estudos sobre pluriatividade. RER, Rio de Janeiro, vol. 45, nº 04, p. 1055-1073, out/dez 2007. Disponível em: https://www.scielo.br/pdf/resr/v45n4/a11v45n4.pdf. Acesso em: 12 jun. 2020.

MONTEIRO, Carlos Augusto de Figueiredo. Geossistemas: a história de uma procura. 2. ed. São Paulo, Contexto, 2001.

MOREIRA, Erika Vanessa. As múltiplas fontes de renda e a pluriatividade nos bairros Aeroporto, Cedro, Córrego da Onça, Ponte Alta e Gramado no município de Presidente Prudente-SP. 265 f. Dissertação (Mestrado) - Programa de PósGraduação em Geografia, Universidade Estadual Paulista "Júlio de Mesquita Filho" Presidente Prudente, São Paulo, 2007.

NAKASHIMA, Paulo. Cartografia dos Sistemas Pedológicos do Noroeste do Paraná - distribuição e subsídios para o controle da erosão. 1999. 162 f. Tese (Doutorado)Programa de Pós-Graduação em Geografia, Universidade de São Paulo, São Paulo, 1999. 
NAKASHIMA, Paulo; NÓBREGA, Maria Teresa de. Solos do Terceiro Planalto do Paraná - Brasil. In: I Encontro Geotécnico do Terceiro Planalto Paranaense. Anais do ENGEOPAR, 2003, Maringá. p. 66- 85.

NÓBREGA, Maria Teresa de; SERRA, Elpídio. Noroeste do Paraná: a dinâmica da paisagem rural nas zonas de contato arenito-basalto. Terra Plural, Ponta Grossa, v.3, n.2, p.197- 213, jul./dez. 2009.

NÓBREGA, Maria Tereza de et al. Landscape structure in the Pirapó, Paranapanema 3 and 4 Hydrographic Unit, in the state of Paraná, Brazil. Braz. J. Biol., vol.75, no.4, suppl.2, p.107-119. 2015.

PARANÁ. Secretaria de Estado do Meio Ambiente e Recursos Hídricos. Bacias hidrográficas do Paraná: série histórica. 2. ed. Curitiba: SEMA, 2013.

SCHNEIDER, Sergio. A pluriatividade na agricultura familiar. $1^{\circ}$ ed. Porto Alegre (RS): Editora da UFRGS, 2003.

A pluriatividade no meio rural brasileiro: características e perspectivas para investigação. In: GRAMMONT, Hubert Carton de; MARTINEZ VALLE, Luciano (Org.). La pluriactividad en el campo latinoamericano. Quito: Ed. Flacso, 2009. v. 1. p. 132-161.

SCHNEIDER, Sergio et al. Pluriatividade e plurirrendimentos nos estabelecimentos agropecuários do Brasil e das Regiões Sul e Nordeste. In: SCHNEIDER, Sergio; FERREIRA, Brancolina; ALVES, Fabio (Org.). Aspectos Multidimensionais da Agricultura Brasileira diferentes visões do Censo Agropecuário 2006. Brasília: Ipea, 2013. p. 105-132.

SERRA, Elpídio. NOROESTE DO PARANÁ: o avanço das lavouras de cana e a nova dinâmica do uso do solo nas zonas de contato arenito-basalto. CAMPO-TERRITÓRIO: Revista de geografia agrária, v. 5, n. 9, p. 89-111, fev., 2010.

SILVA, Sandro Pereira. Agricultura familiar e território: aspectos conceituais e analíticos sobre a multifuncionalidade e a pluriatividade. CAMPO-TERRITÓRIO: Revista de geografia agrária, v. 11, n. 22, p. 243-270, abr., 2016.

SILVEIRA, Laurício Bighelini da; NEUMANN, Pedro Selvino; SANTOS, Vilson Flores dos. Pluriatividade na agricultura família, as diferentes visões teóricas. Anais do VI Encontro da Sociedade Brasileira de Sistemas de Produção. Aracaju, Sergipe, 2004.

VIZINTIM, Miriam Fernandes Barros et al. Sociedade e Natureza: Uma visão geográfica. 1. ed. Londrina: EDUEL, 2012.

Recebido em 01/07/2020.

Aceito para publicação em 15/10/2020. 